\title{
PENGARUH FAKTOR-FAKTOR KUALITAS PELAYANAN TERHADAP KEPUASAN KONSUMEN
}

(STUDI KASUS : KA BANDARA STASIUN SUDIRMAN BARU, BNI CITY)

\author{
Sari Fatmaningsih, Agus Wahyono*) \\ *)Dosen Tetap Program S1 Jurusan Manajemen Fakultas Ekonomi Universitas Satya Negara Indonesia \\ sarifatmaningsih@gmail.com; agoeswahyono@gmail.com
}

\begin{abstract}
This research aims is to understand; 1) the influence of tangible toward to customer satisfaction, 2) the influence of reliability toward to customer satisfaction, 3) the influence of tresponsiveness toward to customer satisfaction, 4) the influence of assurance toward to customer satisfaction, 5) the influence of empathy toward to customer satisfaction, 6) the influence of tangible, reliability, responsiveness, assurance \& empathy toward to Customer satisfaction airport train at Sudirman Baru Station (BNI City).

This research is done by conducting survey. The population of this research are consumers who have used it airport train at Sudirman Baru Station (BNI City). The sampling method done by non probability sampling technique with the sample of 60 people. The data collect method obtained by questionnaires which validity and reliability has been tested. Multiple regression are applied to answer the hypothesis as the analysis method.

The result of this research indicate that; 1) there is influence of tangible has a negative on customer satisfaction, 2) there is influence of reliability has a negative on customer satisfaction, 3) there is influence of responsiveness has a negative on customer satisfaction, 4) there is influence of assurance has a negative on customer satisfaction, 5) there is influence of empathy has a positive on customer satisfaction
\end{abstract}

Keywords :tangible, reliability, responsiveness, assurance, empathy, Consumer Saticfaction.

\section{PENDAHULUAN}

Kemajuan teknologi dan informasi yang cepat dapat membuat pola kehidupan manusia untuk memenuhi kebutuhan hidupnya yang banyak dan beragam dengan cara yang mudah dan cepat. Kereta api adalah alat transportasi ke suatu daerah atau wilayah dan telah menjadi sarana pokok sektor transportasi darat. Untuk dapat melaksanakan fungsinya, kereta api harus ditata secara terpadu sehingga pelayanan terhadap konsumen dapat diberikan dengan baik dan sesuai dengan harapan konsumen itu sendiri. Tata penyelenggaraan kereta api harus sesuai dengan Keputusan Menteri Perhubungan No. PM 60 tahun 2012 tentang Persyaratan Teknis Jalur Kereta Api.

Untuk meningkatkan penyelenggaraan tata transportasi massal seperti kereta api diperlukan pendekatan pelayanan yaitu service quality. Kualitas pelayanan menjadi salah satu bentuk pendekatan untuk menciptakan kepuasan pelanggan (Parasuraman:1994). Tingkat kemacetan yang ada di DKI Jakarta. Menurut catatan Traffic Sorecard Sepanjang 2017 dan dirilis oleh lembaga Inrix menemukan bahwa Jakarta berada di peringkat 12 dalam daftar kota-kota termacet di dunia dan sudah pada tingkat yang akut. Akibatnya banyak masyarakat yang menggunakan jasa ke Bandara sering komplain karena keterlambatan. Salah satu upaya untuk pelayanan publik, maka pemerintah membangun 
transportasi kereta api Bandara Soekarno-Hatta International Airport (SHIA).

Berdasarkan data Kementrian Perhubungan pertumbuhan penerbangan di bandara dari tahun ke tahun mengalami peningkatan. Tingginya kepadatan penumpang ke bandara atau sebaliknya meningkatkan kepadatan transportasi menuju bandara. Di perlukan waktu 3-4 jam dari Jakarta menuju Bandara Soekarno-Hatta atau sebaliknya. Hal tersebut menjadi persoalan bagi penumpang menggunakan jasa ke Bandara Soekarno- Hatta. Untuk mengantipasi hal tersebut Pemerintah melalui Peraturan Presiden (Perpres) No. 83 Tahun 2011, tepatnya bulan Juli 2011 PT. KAI mendapatkan tugas untuk menyelenggarakan Prasarana dan Sarana KA Bandara Soekarno-Hatta International Airport (SHIA) dan Jalur Lingkar Jakarta-Bogor-DepokTangerang-Bekasi. Tanggal 26 Desember 2017 kereta api bandara sudah dioperasikan untuk melayani penumpang di Stasiun Sudirman baru (BNI City) dan diresmikan pada 2 Januari 2018 oleh Presiden Joko Widodo. (sumber : ekonomi.kompas.com)

PT. Railink yang merupakan joint venture PT. Kereta Api Indonesia dan PT. Angkasa Pura II yang kepemilikan sahamnya masing-masing PT. Kereta Api Indonesia 60\% dan PT. Angkasa Pura II 40\%. Peran \& tugas serta fungsi PT. Railink ditunjuk sebagai pengoperasian, pengelolaan, dan pengusahaan kereta api bandara, pengembangan dan pengelolaan stasiun kereta api di bandara dan dipusat kota, pengadaan dan pemeliharaan sarana dan prasarana kereta api, pembangunan prasarana kereta api, konsultasi dan desain sistem perkeretaapian dan pengusahaan jasa lainnya yang menunjang usaha-usaha pokok.

Sesuai dengan Peraturan Presiden Republik Indonesia Nomor 25 Tahun 2009 tentang Pelayanan Publik. Bahwa pelayanan ke masyarakat harus memberikan manfaat sebesar-besarnya bagi publik. PT. Railink sebagai pengoperasian, pengelolaan dan pengusahaan kereta api bandara berupaya memberikan pelayanan yang berkualitas.

Sejak beroperasi pada bulan Januari hingga Desember 2018 tingkat penumpang kereta api menuju bandara maupun sebaliknya, data menunjukan bahwa terdapat kenaikan jumlah penumpang kereta api yang cukup signifikan. Artinya bahwa terjadi pergeseran perilaku masyarakat untuk menggunakan jasa transportasi massal.

Tabel. 1.1

Occupancy Passenger

\begin{tabular}{|c|c|c|c|c|c|}
\hline \multirow{2}{*}{ No } & \multirow{2}{*}{ Month } & \multicolumn{4}{|c|}{ Occupancy } \\
\cline { 3 - 6 } & & \multicolumn{2}{|c|}{ SDB - BST } & \multicolumn{2}{c|}{ BST - SDB } \\
\cline { 3 - 6 } & & Total & Average & Total & Average \\
\hline 1 & Jan & 19.643 & 634 & 28.377 & 915 \\
\hline 2 & Feb & 13.817 & 493 & 17.431 & 623 \\
\hline 3 & Mar & 19.433 & 627 & 22.174 & 715 \\
\hline 4 & Apr & 24.627 & 821 & 26.991 & 900 \\
\hline 5 & Mei & 23.140 & 746 & 25.007 & 807 \\
\hline 6 & Jun & 19.848 & 662 & 20.036 & 668 \\
\hline 7 & Jul & 22.665 & 731 & 25.045 & 808 \\
\hline 8 & Ags & 25.453 & 821 & 25.130 & 811 \\
\hline 9 & Sep & 23.065 & 769 & 22.635 & 755 \\
\hline 10 & Okt & 23.967 & 773 & 23.420 & 755 \\
\hline 11 & Nov & 25.386 & 846 & 24.323 & 811 \\
\hline 12 & Des & 25.251 & 815 & 23.396 & 755 \\
\hline
\end{tabular}

Sumber : PT. Railink 2018

Menurut Tjiptono \& Chandra (2016:115) kualitas yang baik harus memiliki 5 karateristik meliputi : tangibles (bukti langsung) yaitu meliputi fasilitas fisik, perlengkapan, reliability (kehandalan) yaitu kemampuan dalam memberikan pelayanan dengan segera dan memuaskan serta sesuai dengan yang telah dijanjikan, responsiveness (daya tanggap) yaitu keinginan para 
petugas membantu para penumpang dan memberikan pelayanan yang tanggap, assurance (jaminan), empathy (empati) yaitu kemudahan dalam melakukan hubungan, komunikasi yang baik dan perhatian dengan tulus terhadap kebutuhan pelanggan.

Menurut Yamit (2013:8) bahwa harapan pelanggan sesuai dengan apa yang dialami dan dirasakannya, maupun apa yang dialami dan dirasakan melebihi harapannya sudah dapat dipastikan pelanggan tersebut akan puas. Bila yang dialami dan dirasakan pelanggan tidak sesuai dengan harapannya, misalnya pelayanan tidak ramah, tidak tanggap, sudah dipastikan pelanggan tidak merasa puas.

Jadi kualitas pelayanan yang baik akan memberikan pengaruh yang baik terhadap publik. Sebagaimana hal tersebut diungkapkan oleh Kotler \& Keller (2016:153) bahwa pengaruh kualitas pelayanan dengan kepuasan konsumen adalah dimana perasaan seseorang senang atau kecewa yang dihasilkan dari membandingkan kinerja suatu produk yang dirasakan atau hasil dengan harapan.

Berdasarkan uraian diatas, maka pokok permasalahan dalam penelitian ini akan dirumuskan dalam bentuk pertanyaan yaitu sebagai berikut :

1. Apakah tangibles, reliability, responsiveness, assurance dan empathy berpengaruh secara simultan terhadap kepuasan konsumen?

2. Apakah tangibles berpengaruh terhadap kepuasan konsumen ?

3. Apakah reliability berpengaruh terhadap kepuasan konsumen ?

4. Apakah responsiveness terhadap kepuasan konsumen ?

5. Apakah assurance terhadap kepuasan konsumen ?

6. Apakah empathy terhadap kepuasan konsumen?

\section{TINJAUAN LITERATUR}

\section{KUALITAS PELAYANAN}

Menurut Tjiptono dan Chandra (2016:115) kualitas pelayanan sebagai kondisi dinamis yang berhubungan dengan produk, jasa, sumber daya manusia, proses dan lingkungan yang memenuhi atau melebihi harapan. Menurut Yamit (2013:8) kualitas pelayanan sebagai suatu sikap dari hasil perbandingan pengharapan kualitas jasa pelanggan dengan kinerja perusahan yang dirasakan pelanggan. Kualitas bukan hanya menekankan pada aspek hasil akhir, yaitu produk dan jasa tetapi juga menyangkut kualitas manusia, kualitas proses dan kualitas lingkungan.

\section{DIMENSI \& INDIKATOR KUALITAS PELAYANAN}

Menurut Parasuraman, et all (1995) dalam Tjiptono dan Chandra (2016:162) ada 5 dimensi kualitas pelayanan sebagai berikut :

1. Bukti Fisik (tangibles)

Bukti Fisik yaitu berupa peralatan modern, fasilitas yang berdaya tarik visual, karyawan yang berpenampilan rapi dan profesional, materi-materi berkaitan dengan jasa yang berdaya tarik visual. Sedangkan menurut Fandy Tjiptono (2016) : Berwujud yaitu berupa penampilan fisik, peralatan dan berbagai materi yang terlihat dapat dinilai dengan baik. Indikator bukti fisik (tangibles) sebagai berikut :

- Peralatan modern.

- Bersih dan nyaman.

- Penampilan yang rapih.

2. Reliabilitas (reliability) 
Reliabilitas yaitu menyediakan jasa sesuai dengan yang dijanjikan, dapat diandalkan dalam menangani masalah jasa pelanggan, menyampaikan jasa secara benar semenjak pertama kali, menyampaikan jasa sesuai dengan waktu yang dijanjikan, menyimpan cararan atau dokumen tanpa kesalahan. Sedangkan menurut Fandy Tjiptono (2016) :

Keandalan yaitu kemampuan untuk memberikan layanan dengan segera, akurat, konsisten dan memuaskan.

Indicator reliabilitas (reliability) sebagai berikut :

- Kesesuaian pelayanan.

- Ketepatan pelayanan.

- Kemudahan data pelanggan.

3. Daya Tanggap (responsiveness)

Daya Tanggap yaitu menginformasikan pelanggan tentang kepastian waktu penyampaian jasa, layanan yang segera atau cepat bagi pelanggan, kesediaan untuk membantu pelanggan, kesiapan untuk merespon permintaan pelanggan. Fandy Tjiptono (2016) menyatakan bahwa Daya Tanggap yaitu kemauan dan kemampuan dari karyawan memberikan pelayanan secara cepat dan tanggap. Kesigapan para karyawan untuk memenuhi keinginan konsumen dengan tanggap dan ramah.

Indikatior daya tanggap (Responsiveness) sebagai berikut:

- Pelayanan yang cepat tanggap.

- Kesediaan membantu pelanggan.

- Cepat mengatasi keluhan.

4. Jaminan (assurance)

Jaminan yaitu karyawan menumbuhkan rasa percaya pada pelanggan, membuat pelanggan merasa aman sewaktu melakukan transaksi, karyawan yang secara konsisten bersikap sopan, karyawan yang mampu menjawab pertanyaan pelanggan. Fandy Tjiptono (2016) menyatakan bahwa Jaminan yaitu mencakup pengetahuan, kompetensi, kesopanan dan sifat dapat dipercaya yang dimiliki para staff mengenai janji yang diberikan, bebas dari bahaya, resiko, atau keragu-raguan.

indikator jaminan (assurance) sebagai berikut :

- Keramahan dan kesopanan.

- Kepercayaan dan rasa aman penumpang.

- Kemampuan mengatasi persoalan.

5. Empati (empathy)

Empati yaitu memberikan perhatian individual kepada para pelanggan, karyawan yang memperlakukan pelanggan secara penuh perhatian, sungguh-sungguh mengutamakan kepentingan pelanggan, karyawan yang memahami kebutuhan pelanggan, waktu beroperasi (jam kantor) yang nyaman. Fandy Tjiptono (2016) menyatkan bahwa empati yaitu kesediaan karyawan dalam menjalin relasi, komunikasi yang baik, perhatian pribadi dan pemahaman atas kebutuhan individual pelanggan.

Indikator empati (empathy) meliputi:

- Memahami kebutuhan penumpang.

- Melakukan hubungan komunikasi.

- Memiliki kepedulian.

\section{KEPUASAN PELANGGAN}

Menurut Kotler dan Keller (2016:153) kepuasan pelanggan adalah perasaan senang atau kecewa yang muncul setelah membandingkan kinerja (hasil) produk yang dipikirkan terhadap kinerja (atau hasil) yang diharapkan. Menurut Kotler dan Armstrong (2010:150) kepuasan 
pelanggan adalah sejauh mana kinerja suatu produk yang dirasakan sesuai dengan harapan pelanggan. Jika kinerja suatu produk atau jasa jauh dari harapan, maka pelanggan akan merasa tidak puas dan kecewa. Jika kinerja suatu produk atau jasa sesuai dengan harapan, maka pelanggan akan puas. Jika kinerja dari produk atau jasa melebihi harapan, maka pelanggan akan sangat puas dan merasakan kegembiraan.

\section{DIMENSI \& INDIKATOR KEPUASAN PELANGGAN}

Hawkins dan Lonney dalam Tjiptono (2004) menyatakan bahwa atribut pembentuk kepuasan terdiri dari Kesesuaian Harapan, Kesediaan Merekomendasikan, Minat Menggunakan Kembali.

a. Kesesuaian Harapan

Yaitu kesesuaian atau ketidaksesuaian antara harapan konsumen dengan kinerja aktual produk atau jasa perusahaan.

- Kesesuaian fasilitas.

- Kesesuaian pelayanan yang diharapkan.

- Kesesuaian kelengkapan yang diharapkan.

b. Minat Menggunakan Kembali

Yaitu kepuasan pelanggan diukur secara be havioral akan berbelanja atau menggunakan jasa perusahaan lagi.

- Fasilitas memadai.

- Pelayanan yang memuaskan.

- Berminat menggunakan kembali.

c. Kesediaan Merekomendasikan

Yaitu kesediaan untuk merekomendasi produk kepada teman atau keluarganya mernjadi ukuran yang penting untuk di analisis dan ditindaklanjuti. Apabila pelayanan yang diterima atau dirasakan sesuai dengan yang diharapkan, maka kulitas pelayanan dipersepsikan baik dan memuaskan, sehingga akan melakukan pembelian jasa atau memutuskankan untuk menggunakan jasa dan pada akhirnya akan merekomendasikan hal itu kepada orang lain.

- Merekomendasikan ke teman atau keluarga.

- Mengatakan hal-hal positif

\section{KERANGKA BERFIKIR}

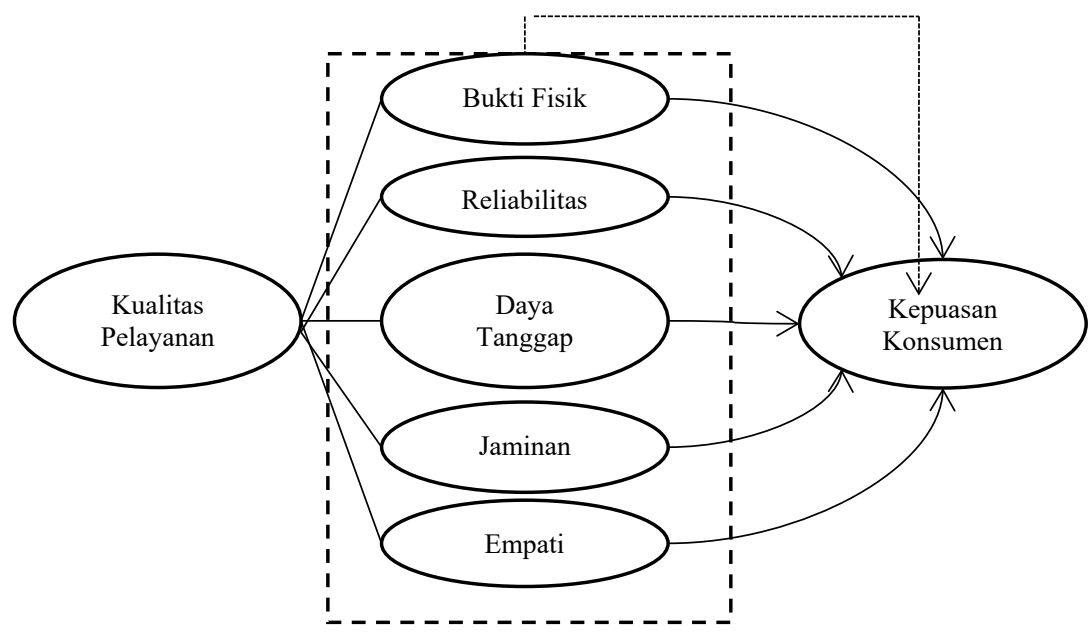

Berdasarkan pada landasan teori dan kerangka berfikir di atas, hipotesis statistika yang diajukan dalam penelitian ini adalah sebagai berikut : 
$\mathrm{Ho}_{1} \beta \leq 0=$ Diduga tidak ada pengaruh Tangible terhadap Kepuasan Konsumen.

$\mathrm{Ha}_{1} \beta>0=$ Diduga ada pengaruh Tangible terhadap Kepuasan Konsumen.

$\mathrm{H}_{02} \beta \leq 0=$ Diduga tidak ada pengaruh Reliability terhadap Kepuasan Konsumen.

$\mathrm{Ha}_{2} \beta>0=$ Diduga ada pengaruh Reliability terhadap Kepuasan Konsumen.

$\mathrm{H}_{03} \beta \leq 0=$ Diduga tidak ada pengaruh Responsiveness terhadap Kepuasan Konsumen.

$\mathrm{Ha}_{3} \beta>0=$ Diduga ada pengaruh Responsiveness terhadap Kepuasan Konsumen.

$\mathrm{H}_{04} \beta \leq 0=$ Diduga tidak ada pengaruh Assurance terhadap Kepuasan Konsumen.

$\mathrm{Ha}_{4} \beta>0=$ Diduga ada pengaruh Assurance terhadap Kepuasan Konsumen.

$\mathrm{H}_{05} \beta \leq 0=$ Diduga tidak ada pengaruh Empathy terhadap Kepuasan Konsumen.

$\mathrm{Ha}_{5} \beta>0=$ Diduga ada pengaruh Empathy terhadap Kepuasan Konsumen.

\section{METODE PENELITIAN}

Penelitian ini dilaksanakan pada Perusahaan PT. Railink Stasiun Sudirman Baru (BNI City). Penumpang KA Bandara yang ada di Stasiun Sudirman Baru (BNI City). Waktu penelitian dilakukan dari awal Oktober 2018 sampai dengan Januari 2019.

\section{Desain Penelitian \& Tekhnik Pengambilan Sampel}

Penelitian ini menggunakan metode penelitian kuantitatif asosiatif. Sugiyono (2015:8) menyatakan bahwa penelitian kuantitatif dapat diartikan sebagai metode penelitian yang berlandaskan pada filsafat positivsm, digunakan untuk meneliti pada populasi atau sampel tertentu, pengumpulan data menggunakan instrument penelitian, analisis data bersifat kuantitatif atau statistic, dengan tujuan untuk menguji hipotesis yang telah di tetapkan. Penelitian asosiatif merupakan penelitian yang bertujuan untuk mengetahui hubungan dua variabel atau lebih (Sugiyono, 2015:36). teknik pengambilan sampel yang digunakan adalah dengan menggunakan nonprobability sampling. Nonprobability sampling adalah teknik pengambilan sampel yang anggota populasinya tidak mempunyai peluang yang sama untuk menjadi anggota sampel (Asnawi, 2009:122).

Teknik pengambilan sampel Non Probability Sampling peneliti menggunakan Acccidental sampling. Menurut Santoso dan Tjiptono (2001:89) accidental sampling adalah prosedur sampling yang memilih sampel dari orang atau unit yang paling mudah dijumpai atau diakses. Sedangkan menurut Sugiyono (2009:221) accidentai sampling adalah mengambil responden sebagai sampel berdasarkan kebetulan, yaitu siapa saja yang secara kebetulan bertemu dengan peneliti dapat digunakan sebagai sampel, bila orang yang kebetulan ditemui cocok sebagai sumber data dengan kriteria utamanya adalah orang tersebut merupakan konsumen atau pelanggan dan sudah menggunakan KA Bandara minimal 1 kali dari KA Bandara Stasiun Sudirman Baru (BNI City).

\section{HASIL \& PEMBAHASAN}

\section{UJI VALIDITAS \& UJI RELIABILITAS}

Hasil uji validitas ternyata semua item pertanyaan valid karena $r_{\text {hitung }}>r_{\text {tabel }}$ dan hasil uji reliabilitas semua item variabel dinyatakan reliabel karena nilai Cronbach Alpha menunjukan $>$ 0,6 , maka semua variabel dikatakan reliabel. 
Tabel. 1.2

Hasil Uji Reliabilitas

\begin{tabular}{|l|c|c|}
\hline \multicolumn{1}{|c|}{ Variabel } & Cronbach Alpha & Keterangan \\
\hline Bukti Fisik & 0,887 & Reliabel \\
\hline Reliabilitas & 0,908 & Reliabel \\
\hline Daya Tanggap & 0,785 & Reliabel \\
\hline Jaminan & 0,891 & Reliabel \\
\hline Empati & 0,885 & Reliabel \\
\hline Kepuasan Konsumen & 0,944 & Reliabel \\
\hline
\end{tabular}

Sumber : Hasil Pengolahan Data, 2019

\section{UJI NORMALITAS}

1. Uji Normalitas Histogram P-Plot, data menyebar disekitar garis diagonal dan mengikuti arah diagonal maka distribusi data normal.

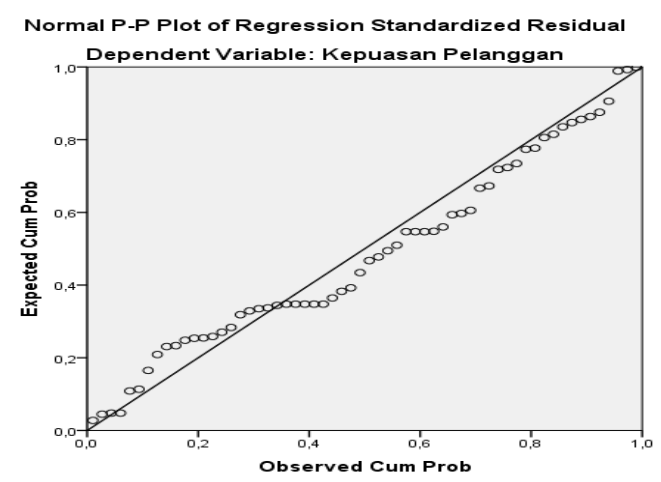

Sumber : Hasil Pengolahan Data, 2019

2. Uji Normalitas menggunakan uji statistik non parametik Kolmogorov-Smirnov (K-S), dapat dilihat dari nilai Asymp. Sig. (2-tailed). Sehingga dapat dilihat bahwa nilai signifikan dari tiap-tiap variabel $>0,05$ dapat dikatakan bahwa asumsi yang diisyaratkan untuk uji regresi tersebut berdistribusi normal atau dengan kata lain bahwa model regresi ini dapat dilanjutkan.

Tabel 4.10

Hasil Uji Normalitas Kolmogorov-Smirnov

One-Sample Kolmogorov-Smirnov Test

\begin{tabular}{|ll|r|}
\hline & & Unstandardized Residual \\
\hline $\mathrm{N}$ & & 60 \\
Normal Parameters $^{\mathrm{a}, \mathrm{b}}$ & Mean &, 0000000 \\
& Std. & 2,77270605 \\
& Deviation & \\
Most Extreme & Absolute &, 118 \\
Differences & Positive &, 118 \\
& Negative &,- 113 \\
Kolmogorov-Smirnov Z & &, 917 \\
Asymp. Sig. (2-tailed) & &, 370 \\
\hline
\end{tabular}

a. Test distribution is Normal.

b. Calculated from data.

Sumber : Hasil Pengolahan Data, 2019 


\section{UJI MULTIKOLINIERITAS}

Dikertahui bahwa nilai Tolerance untuk variabel bukti fisik (tangibles) $\left(\mathrm{X}_{1}\right)$ adalah sebesar 0,572, reliabilitas (reliability) $\left(\mathrm{X}_{2}\right)$ adalah sebesar 0,313, daya tanggap (responsiveness) $\left(\mathrm{X}_{3}\right)$ adalah sebesar 0,389, jaminan (assurance) adalah $\left(\mathrm{X}_{4}\right)$ sebesar adalah 0,255, Empati (empathy) $\left(\mathrm{X}_{5}\right)$ adalah sebesar 0,255. Sedangkan nilai VIF (Variance Inflation Factor) untuk variabel bukti fisik (tangibles) $\left(\mathrm{X}_{1}\right)$ adalah sebesar 1,750, reliabilitas (reliability) $\left(\mathrm{X}_{2}\right)$ adalah sebesar 3,192, daya tanggap (responsiveness) $\left(\mathrm{X}_{3}\right)$ adalah sebesar 2,569, jaminan (assurance) $\left(\mathrm{X}_{4}\right)$ adalah sebesar 3,923, empati (empathy) $\left(\mathrm{X}_{5}\right)$ adalah sebesar 4,443.

Maka dapat disimpulkan bahwa tidak terjadi multikolinieritas antar variabel bebas, karena nilai Tolerance untuk masing-masing variabel adalah lebih besar dari 0,1 dan nilai VIF (Variance Inflation Factor) untuk masing-masing variabel lebih kecil dari 10.

Tabel 1.3

Hasil Uji Multikolinearitas

Coefficients $^{\mathrm{a}}$

\begin{tabular}{|c|c|c|c|c|c|c|c|}
\hline \multirow[b]{2}{*}{ Model } & \multicolumn{2}{|c|}{$\begin{array}{c}\text { Unstandardized } \\
\text { Coefficients }\end{array}$} & \multirow{2}{*}{$\begin{array}{c}\begin{array}{c}\text { Standardized } \\
\text { Coefficients }\end{array} \\
\text { Beta }\end{array}$} & \multirow[b]{2}{*}{$\mathrm{t}$} & \multirow[b]{2}{*}{ Sig. } & \multicolumn{2}{|c|}{ Collinearity Statistics } \\
\hline & $\mathrm{B}$ & $\begin{array}{l}\text { Std. } \\
\text { Error }\end{array}$ & & & & Tolerance & VIF \\
\hline $1 \quad$ (Constant) & 6,789 & 4,982 & & 1,363 & ,179 & & \\
\hline Tangibles & ,319 &, 160 & , 197 & 1,997 & 051 &, 572 & 1,750 \\
\hline Reliability &,- 215 &, 177 &,- 162 & $-1,213$ &, 230 & ,313 & 3,192 \\
\hline Responsiveness & ,212 & ,206 &, 123 & 1,031 & ,307 & ,389 & 2,569 \\
\hline Assurance & ,365 & 241 & 224 & 1,517 &, 135 & ,255 & 3,923 \\
\hline Empathy & 1,310 & ,378 &, 545 & 3,463 & 001 & ,225 & 4,443 \\
\hline
\end{tabular}

a. Dependent Variable: Kepuasan Pelanggan

Sumber : Hasil Pengolahan Data, 2019

\section{UJI HETEROSKEDASTISITAS}

Pengujian Heteroskedastisitas dalam penelitian ini menggunakan grafik scatterplot, dari grafik scatterplot terlihat bahwa titik-titik menyebar secara acak serta tersebar baik diatas maupun dibawah angka 0 pada sumbu $\mathrm{Y}$, hal ini dapat disimpulkan bahwa tidak terjadi heteroskedastisitas pada model regresi, sehingga model regresi layak dipakai untuk memprediksi $\mathrm{Y}$ berdasarkan masukan variabel independent $\mathrm{X}_{1}, \mathrm{X}_{2}, \mathrm{X}_{3}, \mathrm{X}_{4}$, dan $\mathrm{X}_{5}$.

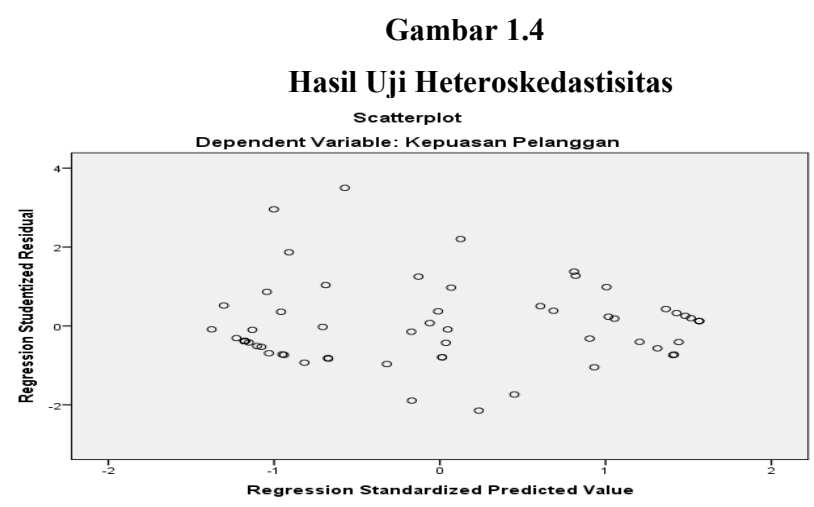

Sumber: Hasil Pengolahan Data, 2019 


\section{UJI AUTOKORELASI}

Penelitian ini menggunakan Uji Durbin Watson (DW test) sebagai analisis data. Dimana nilai DL dan DU diperoleh dengan melihat tabel statistik Durbin Watson pada tingkat signifikansi $\alpha=5 \%, \mathrm{k}=5$ (jumlah variabel bebas yaitu $\mathrm{X}_{1}, \mathrm{X}_{2}, \mathrm{X}_{3}, \mathrm{X}_{4}, \mathrm{X}_{5}$ ), kemudian diperoleh nilai $\mathrm{DL}=$ 1,408 dan nilai $\mathrm{DU}=1,767$ dengan $\mathrm{n}=60$ (jumlah responden), nilai dari $\mathrm{DW}=1,685$ yang diperolah dari hal pengolahan data dan 4-DU $=2,233$ dengan SPSS versi 20. Karena nilai Durbin Waston terletak antara DL $\leq \mathrm{DW} \leq \mathrm{DU}$ adalah $(1,408<1,685<1,767)$ artinya tidak ada korelasi positif.

Tabel 1.5

Hasil Autokorelasi

Model Summary

\begin{tabular}{|c|c|c|c|c|c|}
\hline Model & $\mathrm{R}$ & R Square & $\begin{array}{c}\text { Adjusted R } \\
\text { Square }\end{array}$ & $\begin{array}{l}\text { Std. Error of the } \\
\text { Estimate }\end{array}$ & Durbin-Watson \\
\hline 1 &, $836^{\mathrm{a}}$ & ,699 & 671 & 2,89823 & 1,685 \\
\hline
\end{tabular}

a. Predictors: (Constant), Tangibles, Responsiveness, Reliability, Assurance, Empathy

b. Dependent Variable: Kepuasan Pelanggan

Sumber : Hasil Pengolahan Data, 2019

\section{UJI HIPOTESIS}

\section{ANALISIS REGRESI LINEAR BERGANDA}

Persamaan regresi berganda berdasarkan hasil analisi regresi dapat diketahui sebagai berikut :

Tabel 1.6

Hasil Analisis Regresi Linear Berganda

Coefficients $^{\mathrm{a}}$

\begin{tabular}{|c|c|c|c|c|c|}
\hline \multirow[b]{2}{*}{ Model } & \multicolumn{2}{|c|}{ Unstandardized Coefficients } & \multirow{2}{*}{$\begin{array}{c}\text { Standardized } \\
\text { Coefficients } \\
\text { Beta } \\
\end{array}$} & \multirow[b]{2}{*}{$\mathrm{T}$} & \multirow[b]{2}{*}{ Sig. } \\
\hline & $\mathrm{B}$ & Std. Error & & & \\
\hline (Constant) & 6,789 & 4,982 & & 1,363 & , 179 \\
\hline Tangibles & ,319 &, 160 & , 197 & 1,997 &, 051 \\
\hline Reliability &,- 215 & , 177 &,- 162 & $-1,213$ & ,230 \\
\hline Responsiveness & ,212 & ,206 & , 123 & 1,031 & ,307 \\
\hline Assurance & ,365 & ,241 & ,224 & 1,517 & , 135 \\
\hline Empathy & 1,310 & ,378 & ,545 & 3,463 & 001 \\
\hline
\end{tabular}

a. Dependent Variable: Kepuasan Pelanggan

Sumber : Hasil Pengolahan Data, 2019

$\mathrm{Y}=6,789+0,319 \mathrm{X}_{1}-0,215 \mathrm{X}_{2}+0,212 \mathrm{X}_{3}+$

$0,365 \mathrm{X}_{4}+1,310 \mathrm{X}_{5}+\mathrm{e}$

Adapun penjelasan dari persamaan regresi linear berganda diatas adalah sebagai berikut : 
1. Nilai konstanta sebesar 6,789 artinya apabila bukti fisik (tangibles), reliabilitas (reliability), daya tanggap (responsiveness), jaminan (assurance), dan empati (empathy) sama dengan 0 , maka kepuasan konsumen memiliki nilai 6,789.

2. Nilai koefisien bukti fisik (tangibles) sebesar 0,319, artinya apabila bukti fisik (tangibles) meningkat, maka kepuasan konsumen KA Bandara Stasiun Sudirman Baru juga akan meningkat sebesar 0,319 dengan asumsi variabel lain konstan.

3. Nilai koefisien reliabilitas (reliability) sebesar -0,215, artinya apabila reliabilitas (reliability) menurun, maka kepuasan konsumen KA Bandara Stasiun Sudirman Baru juga akan meningkat sebesar -0,215 dengan asumsi variabel lain konstan.

4. Nilai koefisien daya tanggap (responsiveness) sebesar 0,212 , artinya apabila daya tanggap (responsiveness) meningkat, maka kepuasan konsumen KA Bandara Stasiun Sudirman Baru juga akan meningkat sebesar 0,212 dengan asumsi variabel lain konstan.

5. Nilai koefisien jaminan (assurance) sebesar 0,365, artinya apabila jaminan (assurance) meningkat, maka kepuasan konsumen KA Bandara Stasiun Sudirman Baru juga akan meningkat sebesar 0,365 dengan asumsi variabel lain konstan.

6. Nilai koefisien empati (empathy) sebesar 1,310, artinya apabila empati (empathy) meningkat, maka kepuasan konsumen KA Bandara Stasiun Sudirman Baru juga akan meningkat sebesar 1,310 dengan asumsi variabel lain konstan.

\section{UJI F}

Dari hasil uji $\mathrm{F} /$ ANOVA diperoleh $\mathrm{F}_{\text {hitung }}$ sebesar 25,031 df (jumlah kelompok data -1) = $5-1=4$, df $2=(n-5)=60-5=55$. Hasil diperoleh F tabel sebesar 2,540. Nilai Fhitung $>$ Ftabel $(25,031>2,540)$ dan nilai probabilitas (signifikan) adalah sebesar 0,000 . Karena nilai signifikasi $0,000<0,05$. Maka dapat disimpulkan bahwa variabel bukti fisik (tangibles) $\left(\mathrm{X}_{1}\right)$, reliabilitas (reliability) $\left(\mathrm{X}_{2}\right)$, daya tanggap (responsiveness) $\left(\mathrm{X}_{3}\right)$, jaminan (assurance) $\left(\mathrm{X}_{4}\right)$, dan empati (empathy) $\left(\mathrm{X}_{5}\right)$ secara bersamaan atau simultan berpengaruh positif terhadap kepuasan konsumen (Y) di Stasiun Sudirman Baru (BNI City). Dengan demikian Ha diterima dan $\mathrm{H}_{0}$ ditolak.

Tabel 1.7

Hasil Uji Signifikasi F

ANOVA $^{\mathrm{a}}$

\begin{tabular}{|c|c|c|c|c|c|}
\hline Model & Sum of Squares & df & $\begin{array}{l}\text { Mean } \\
\text { Square }\end{array}$ & $\mathrm{F}$ & Sig. \\
\hline 1 Regression & 1051,264 & 5 & 210,253 & 25,031 &, $000^{\mathrm{b}}$ \\
\hline Residual & 453,586 & 54 & 8,400 & & \\
\hline Total & 1504,850 & 59 & & & \\
\hline
\end{tabular}

a. Dependent Variable: Kepuasan Pelanggan

b. Predictors: (Constant), Tangibles, Responsiveness, Reliability, Assurance, Empathy

Sumber : Hasil Pengolahan Data, 2019

\section{UJI t}


Pengujian dilakukan dengan tingkat signifikasi dengan $t_{\text {hitung, apabila nilai signifikasi }}<0,05$ dan $t_{\text {hitung }}>t_{\text {tabel}}$, maka dapat disimpulkan bahwa variabel independent secara parsial berpengaruh positif terhadap variabel dependen.

Tabel 1.7

Hasil Uji Signifikasi t

Coefficients $^{\mathrm{a}}$

\begin{tabular}{|c|c|c|c|c|c|}
\hline \multirow[b]{2}{*}{ Model } & \multicolumn{2}{|c|}{ Unstandardized Coefficients } & \multirow{2}{*}{$\begin{array}{c}\begin{array}{c}\text { Standardized } \\
\text { Coefficients }\end{array} \\
\text { Beta } \\
\end{array}$} & \multirow[b]{2}{*}{$\mathrm{T}$} & \multirow[b]{2}{*}{ Sig. } \\
\hline & B & Std. Error & & & \\
\hline 1 (Constant) & 6,789 & 4,982 & & 1,363 & , 179 \\
\hline Tangibles & ,319 & , 160 & ,197 & 1,997 & ,051 \\
\hline Reliability &,- 215 & ,177 &,- 162 & $-1,213$ & ,230 \\
\hline Responsiveness & ,212 & ,206 & ,123 & 1,031 & ,307 \\
\hline Assurance & ,365 & ,241 &, 224 & 1,517 & ,135 \\
\hline Empathy & 1,310 & ,378 & ,545 & 3,463 & ,001 \\
\hline
\end{tabular}

a. Dependent Variable: Kepuasan Pelanggan

Sumber : Hasil Pengolahan Data, 2019

1. Maka tidak terdapat pengaruh dan tidak signifikan bukti fisik (tangibles) terhadap kepuasan konsumen. Berdasarkan tabel bahwa $t_{\text {hitung }} 1,997<t_{\text {tabel }} 2,004$ dan signifikan 0,051 $>0,05$ dengan demikian $\mathrm{Ho}_{1}$ diterima dan $\mathrm{Ha}_{1}$ ditolak. Sehingga secara parsial tidak terdapat pengaruh antara bukti fisik (tangibles) terhadap kepuasan konsumen.

2. Maka tidak terdapat pengaruh dan tidak signifikan reliabilitas (reliability) terhadap kepuasan konsumen. Berdasarkan tabel bahwa $t_{\text {hitung }}-1,213<t_{\text {tabel }} 2,004$ dan signifikan $0,230>0,05$ dengan demikian $\mathrm{H}_{\mathrm{O} 2}$ diterima dan $\mathrm{Ha}_{2}$ ditolak. Sehingga secara parsial tidak terdapat pengaruh antara reliabilitas (reliability) terhadap kepuasan konsumen.

3. Maka tidak terdapat pengaruh dan tidak signifikan daya tanggap (responsiveness) terhadap kepuasan konsumen. Berdasarkan tabel bahwa $t_{\text {hitung }} 1,031<\mathrm{t}_{\text {tabel }} 2,004$ dan signifikan 0,307 $>0,05$ dengan demikian $\mathrm{Ho}_{3}$ diterima dan $\mathrm{Ha}_{3}$ ditolak. Sehingga secara parsial tidak terdapat pengaruh antara daya tanggap (responsiveness) terhadap kepuasan konsumen.

4. Maka tidak terdapat pengaruh dan tidak signifikan jaminan (assurance) terhadap kepuasan konsumen. Berdasarkan tabel bahwa $t_{\text {hitung }} 1,517<\mathrm{t}_{\text {tabel }} 2,004$ dan signifikan $0,135>0,05$ dengan demikian $\mathrm{Ho}_{4}$ diterima dan $\mathrm{Ha}_{4}$ ditolak. Sehingga secara parsial tidak terdapat pengaruh antara jaminan (assurance) terhadap kepuasan konsumen.

5. Maka terdapat pengaruh dan signifikan empati (empathy) terhadap kepuasan konsumen. Berdasarkan tabel bahwa $t_{\text {hitung }} 3,463>\mathrm{t}_{\text {tabel }} 2,004$ dan signifikan 0,001 $<0,05$ dengan demikian $\mathrm{Ho}_{5}$ ditolak dan $\mathrm{Ha}_{5}$ diterima. Sehingga secara parsial terdapat pengaruh antara empati (empathy) terhadap kepuasan konsumen.

\section{UJI KOEFISIEN DETERMINASI $\left(\mathrm{R}^{2}\right)$}

Pada tabel 4.18 diatas nilai $\mathrm{R}$ menunjukan korelasi sederhana (korelasi pearson) antara variabel $\mathrm{X}$ terhadap variabel $\mathrm{Y}$ diperoleh nilai 0,836 artinya korelasi antara variabel $\mathrm{X}$ (tangibles, reliability, responsiveness, assurance \& empathy) terhadap kepuasan konsumen sebesar 0,836. Hal ini berarti terjadi hubungan yang kuat karena nilai diatas $>0,50$ dan mendekati 1 . 
Nilai $\mathrm{R}^{2}$ adalah 0,699 dan nilai Adjusted $\mathrm{R}^{2}$ sebesar 0,671. Dalam hal ini berarti $67,1 \%$ menunjukan bahwa persentase sumbangan pengaruh variabel independent (tangibles, reliability, responsiveness, assurance \& empathy) terhadap variabel dependent. Sedangkan sisanya sebesar $32,9 \%(100 \%-67,1 \%)$ dipengaruhi atau dijelaskan oleh variabel lain yang tidak diketahui dan tidak masuk dalam penelitian ini.

Tabel 4.

Hasil Koefisien Determinasi $\left(\mathbf{R}^{2}\right)$

\begin{tabular}{|l|r|r|r|r|}
\hline & & & & \\
\hline & & & Model Summary \\
Model & $\mathrm{R}$ & R Square & $\begin{array}{c}\text { Adjusted R } \\
\text { Square }\end{array}$ & $\begin{array}{c}\text { Std. Error of the } \\
\text { Estimate }\end{array}$ \\
\hline 1 &, $836^{\mathrm{a}}$ &, 699 &, 671 & 2,89823 \\
\hline
\end{tabular}

a. Predictors: (Constant), Tangibles, Responsiveness, Reliability, Assurance, Empathy

b. Dependent Variable: Kepuasan Pelanggan

Sumber : Hasil Pengolahan Data, 2019

\section{PEMBAHASAN}

\section{Pengaruh Bukti Fisik (tangibles) $\left(\mathrm{X}_{1}\right)$ Terhadap Kepuasan Konsumen (Y)}

Dari hasil penelitian ini diketahui bahwa bukti fisik (tangibles) yang ada di KA Bandara Stasiun Sudirman Baru (BNI City) tidak memiliki pengaruh signifikan terhadap kepuasan konsumen. Dibuktikan dengan nilai $t_{\text {hitung }} 1,997<\mathrm{t}_{\text {tabel }} 2,004$ dengan tingkat signifikan $0,051>$ 0,05 .

Dimensi yang memiliki score terbesar adalah bersih dan nyaman, dengan instrument "Fasilitas lingkungan area stasiun terlihat bersih dan nyaman". Dan pada instrumen "Peralatan dan perlengakapan kerja KA Bandara menggunakan teknologi terbaru" mayoritas pelanggan sepakat bahwa masih perlu diperhatikan kembali, karena instrumen ini memiliki score terendah. Dalam hal ini biasanya perusahaan mensosialisasikan hal-hal terkait guna meningkatkan kepuasan pelanggan.

Hasil penelitian ini sejalan dengan penelitian Mutiara Ayu \& Achmad Slamet (2015) yang menyatakan variabel bukti fisik (tangibles) tidak berpengaruh terhadap kepuasan pelanggan.

\section{Pengaruh Reliabilitas (reliability) $\left(\mathbf{X}_{2}\right)$ Terhadap Kepuasan Konsumen (Y)}

Dari hasil penelitian ini diketahui bahwa reliabilitas (reliability) yang ada di KA Bandara Stasiun Sudirman Baru (BNI City) tidak memiliki pengaruh signifikan terhadap kepuasan konsumen. Dibuktikan dengan nilai $t_{\text {hitung }}-1,213<t_{\text {tabel }} 2,004$ dengan tingkat signifikan $0,230>$ 0,05 .

Dimensi yang memiliki score terbesar adalah ketepatan pelayanan, dengan instrument "Petugas/ karyawan KA Bandara memberikan pelayanan yang dapat dipercaya". Dan pada dimensi kesesuaian pelayanan, instrumen "Petugas/ karyawan KA Bandara memiliki kehandalan dalam melayani pelanggan" mayoritas pelanggan sepakat bahwa masih perlu diperhatikan kembali, karena instrumen ini memiliki score terendah. Dalam hal ini biasanya perusahaan mensosialisasikan hal-hal terkait guna meningkatkan kepuasan pelanggan.

Hasil penelitian ini sejalan dengan penelitian Veronica Diona Mahardhika K (2016), Giri Kusnanto (2018) \& Richa Mega Puspita (2018) yang menyatakan variabel reliabilitas (reliability) tidak berpengaruh terhadap kepuasan pelanggan.

\section{Pengaruh Daya Tanggap (responsiveness) $\left(\mathrm{X}_{3}\right)$ Terhadap Kepuasan Konsumen (Y)}


Dari hasil penelitian ini diketahui bahwa daya tanggap (responsiveness) yang ada di KA Bandara Stasiun Sudirman Baru (BNI City) tidak memiliki pengaruh signifikan terhadap kepuasan konsumen. Dibuktikan dengan nilai thitung $1,031<t_{\text {tabel }} 2,004$ dengan tingkat signifikan $0,307>0,05$.

Dimensi yang memiliki score terbesar adalah pelayanan yang cepat tanggap, dengan instrument "Pelayanan petugas/ karyawan KA Bandara merespon cepat keluhan pelanggan". Dan pada dimensi cepat mengatasi keluhan, instrumen "Petugas/ karyawan KA Bandara yang tidak responsif dalam memberikan informasi" mayoritas pelanggan sepakat bahwa masih perlu diperhatikan kembali, karena instrumen ini memiliki score terendah. Dalam hal ini biasanya perusahaan mensosialisasikan hal-hal terkait guna meningkatkan kepuasan pelanggan.

Hasil penelitian ini sejalan dengan penelitian Veronica Diona Mahardhika K (2016) yang menyatakan variabel daya tanggap (responsiveness) tidak berpengaruh terhadap kepuasan pelanggan.

\section{Pengaruh Jaminan (assurance) $\left(\mathbf{X}_{4}\right)$ Terhadap Kepuasan Konsumen (Y)}

Dari hasil penelitian ini diketahui bahwa jaminan (assurance) yang ada di KA Bandara Stasiun Sudirman Baru (BNI City) tidak memiliki pengaruh signifikan terhadap kepuasan konsumen. Dibuktikan dengan nilai $t_{\text {hitung }} 1,517<\mathrm{t}_{\text {tabel }} 2,004$ dengan tingkat signifikan $0,135>$ 0,05 .

Dimensi yang memiliki score terbesar adalah kepercayaan dan rasa aman penumpang, instrument "Kemampuan pelayanan KA Bandara akan rasa aman \& kenyaman penumpang diutamakan". Dan pada instrumen "Petugas/ karyawan KA Bandara memiliki pengetahuan dalam melakukan pelayanan" mayoritas pelanggan sepakat bahwa masih perlu diperhatikan kembali, karena instrumen ini memiliki score terendah. Dalam hal ini biasanya perusahaan mensosialisasikan hal-hal terkait guna meningkatkan kepuasan pelanggan.

Hasil penelitian ini sejalan dengan penelitian Frieyadie dan Dewi Alramuri (2017) yang menyatakan variabel jaminan (assurance) tidak berpengaruh terhadap kepuasan pelanggan.

\section{Pengaruh Empati (empathy) $\left(\mathrm{X}_{5}\right) \quad$ Terhadap Kepuasan Konsumen (Y)}

Dari hasil penelitian ini diketahui bahwa empati (empathy) yang ada di KA Bandara Stasiun Sudirman Baru (BNI City) memiliki pengaruh signifikan terhadap kepuasan konsumen. Dibuktikan dengan nilai $t_{\text {hitung }} t_{\text {hitung }} 3,463>\mathrm{t}_{\text {tabel }} 2,004$ dengan tingkat signifikan 0,001 $<0,05$.

Dimensi yang memiliki score terbesar adalah melakukan hubungan komunikasi, instrument "Petugas/ karyawan KA Bandara membangun hubungan yang komunikatif (tersenyum) dengan pelanggan". Dan pada dimensi memahami kebutuhan penumpang, instrumen "Petugas/ karyawan KA Bandara memahami kebutuhan pelanggan" mayoritas pelanggan sepakat bahwa masih perlu diperhatikan kembali, karena instrumen ini memiliki score terendah. Dalam hal ini biasanya perusahaan mensosialisasikan hal-hal terkait guna meningkatkan kepuasan pelanggan.

Hasil penelitian ini sejalan dengan penelitian Mutiara Ayu \& Achmad Slamet (2015), Veronica Diona Mahardhika K (2016), Frieyadie \& Dewi Alramuri (2017), Giri Kusnanta (2018) \& Putu Siti Firmani (2018) yang menyatakan variabel empati (empathy) berpengaruh terhadap kepuasan pelanggan.

\section{KESIMPULAN}

Berdasarkan pada hasil analisis yang telah dilakukan pada penelitian ini, maka dapat ditarik kesimpulan hasil uji regresi linear berganda menghasilkan hubungan bahwa empathy merupakan variabel yang memiliki koefisiensi regresi terbesar. Hasil Uji t adalah : tangible, reliability, responsiveness dan assurance berpengaruh tidak signifikan terhadap kepuasan konsumen KA Bandara Stasiun Sudirman Baru, BNI City, sedangkan empathy berpengaruh 
signifikan terhadap kepuasan konsumen KA Bandara Stasiun Sudirman Baru, BNI City. Hasil Uji F adalah: ada pengaruh signifikan antara variabel tangible, reliability, responsiveness, assurance dan empathy secara simultan terhadap kepuasan konsumen KA Bandara Stasiun Sudirman Baru, BNI City. Hasil Uji $\mathrm{R}^{2}$ adalah : 0,671 berarti dapat diketahui bahwa pengaruh yang diberikan oleh variabel tangible, reliability, responsiveness, assurance dan empathy terhadap kepuasan konsumen KA Bandara Stasiun Sudirman Baru, BNI City adalah sebesar 67,1\% sedangkan sisanya $32,9 \%$ dipengaruhi oleh faktor lain yang tidak diteliti.

\section{SARAN}

Berdasarkan hasil pembahasan di atas mengenai pengaruh faktor-faktor kualitas pelayanan terhadap kepuasan konsumen KA Bandara di Stasiun Sudirman Baru (BNI City), peneliti mengajukan beberapa saran sebagai bahan masukan dan pertimbangan :

Bagi PT. Railink

1. Tangible, dengan meningkatkan kualitas pelayanan dalam penggunaan peralatan dan perlengkapan (vending machine) yang tersedia di Stasiun Sudirman Baru, karena mayoritas pelanggan sepakat bahwa pelanggan masih belum terlalu familiar terhadap teknologi tersebut.

2. Responsiveness, petugas/karyawan harus bersikap responsif dalam memberikan informasi kepada pelanggan.

3. Assurance, dengan meningkatkan kinerja petugas/karyawan dalam melayani konsumen dengan memiliki pengetahuan dalam melakukan pelayanan dengan profesisionel, dan meningkatkan jaminan keamanan dan kenyamanan konsumen serta jaminan asuransi keselamatan KA Bandara Stasiun Sudirman Baru, BNI City.

4. Empathy, dengan meningkatkan kesadaran petugas/karyawan untuk selalu melayani dan mengutamakan kebutuhan konsumen, serta membantu penumpang yang memerlukan bantuan seperti lansia.

5. Pada variabel reliability menunjukan hubungan yang tidak searah, artinya reliability Stasiun Sudirman Baru yang ditunjukan masih belum maksimal. Perusahaan harus memperhatikan kehandalan petugas/karyawan guna meningkatkan kepuasan konsumen dengan tetap memperhatikan faktor-faktor lain yang dijadikan tolak ukur sejauh mana kinerja perusahaan dalam memberikan kepuasan kepada konsumen.

\section{DAFTAR PUSTAKA}

Abbas, Salim. 2008. Manajemen Transportasi, Graha Ilmu. Yogyakarta

Adisasmita, Sakti Adji. 2011. Transportasi dan Pengembangan Wilayah.

Kamaludin, Rustian. 1987. Ekonomi Transportasi. Ghalia Indonesia. Jakarta

Kotler, Philip and Kevin Lane Keller, 2016. Marketing Management, 15th Edition, Pearson Education, Inc. 153

Kotler, Amstrong. 2010. Principles Of Marketing. 13 Edition. New Jersey. Upper Saddle River: Pearson Prentice Hall

Kotler, Philip and Kevin Lane Keller, 2016. Marketing Management, 15th Edition, Pearson Education, Inc. 153

Morlok, E.K. 1984. Pengantar Teknik dan Perencanaan Transportasi. Jakarta, Erlangga

Nasution, M, (2005), "Total Quality Management", PT Gramedia Pustaka Utama : Jakarta

Parasuraman, A., Zeithaml, V.A dan Berry, L.L., 1994, "Reassessment of Expectations as a Comparison Standart in Measuring Service Quality : Implication for Futher Research" Journal of Marketing, January.

Parasuraman, A. A. Zeithaml, V., and L. Berry, L. 1995. "A Conceptual Model of Service Quality and Its Implcations for Future Research". Journal of Marketing. Vol 49 (fall) 
Republik Indonesia, Peraturan Presiden Nomor 83 / Perpres / 2011. Tentang Penugasan Kepada PT. KAI Untuk Menyelenggarakan Prasarana dan Sarana KA Bandara Soekarno-Hatta International Airport (SHIA) dan Jalur Lingkar Jakarta-Bogor-Depok-Tangerang-Bekasi Republik Indonesia, Peraturan Presiden Nomor 25 / Perpres / 2009. Tentang Pelayanan Publik. Tjiptono, Fandy. 2004. Perspektif Manajemen dan Pemasaran Kontemporer. Yogyakarta : Andi. Tjiptono, F., \& Chandra, G. 2016. Service, quality and saticfaction, Yogyakarta : Andi

\section{JURNAL}

Frieyadie \& Dewi Alramuri. 2017. Implementasi Metode Fuzzy Servqual Untuk Menilai Pelayanan Customer Service Terhadap Kepuasan Pelanggan di PT. Telkom Jurnal Techno Nusa Mandiri Vol 14, No. 2, September 2017

Giri Kusnanta. 2018. Analisis Pengaruh Kualitas Pelayanan Terhadap Kepuasan Pelanggan Pada Perusahaan Transportasi Jasa PT. Sriwijaya Air. Journal of Tourism and Economic. Volume 1 No. 1 2018, Page 28-37

https://www.railink.co.id/ diunduh 2018

Kamaludin, Rustian. 1987. Ekonomi Transportasi. Ghalia Indonesia. Jakarta

Mutiara Ayu \& Achmad Slamet. 2015. Analisis Kepuasan Pelanggan Mengenai Kualitas Pelayanan Astra Motor Slawi di Kabupaten Tegal. Management Analysis Journal. 4 (4) (2015)

Muhammad Irzal Adiakurnia. 2017. Aneka Fasilitas ala Pesawat di Kereta Api Bandara Soekarno-Hatta. https://travel.kompas.com/read/2017/11/23/183000227/aneka-fasilitas-alapesawat-di-kereta-bandara-soekarno-hatta. diunduh 2018

Putu Siti Firmani. 2018. Analisis Pengaruh Kualitas Pelayanan Terhadap Kepuasan Konsumen Menggunakan Jasa Transportasi Pada PT. Cakra Transport Utama. Journal. Journal Vol. 19 No. 1, April 2018

Richa Mega Puspita \& Singgih Santoto. 2018. Pengaruh Kualitas Pelayanan dan fasilitas Pendukung Terhadap Kepuasan Pelanggan Stasiun Lempuyangan Yogyakarta. Journal. Vol. 13 No. 1, April 2018.

Sarjono, haryadi., dan Julianita, Winda. 2011. SPSS vs LISREL : Sebuah Pengantar, Aplikasi untuk Riset. Penerbit Salemba empat, Jakarta

Veronica Diona Mahardhika. K. 2016. Pengaruh Kualitas Pelayanan Terhadap Kepusaan Konsumen Jasa Transportasi Kereta Api Indonesia (KAI) Daerah Operasi 6 Yogyakarta Journal . Journal Vol 3 No. 1, Maret 2016

Vidya Metayunika (2013). Analisis Pengaruh Kualitas Pelayanan (Tangible, Relibility, Responsiveness, Assurance dan Empathy) Terhadap Kepuasan Konsumen (Studi Pada Dealer Mitsubishi Pt Bumen Redja Abadi Semarang). Universitas Diponegoro Semarang 